Politics \& Society, vol. 9, núm. 3, 1980, pp. 323-370.

\title{
Varieties of Marxist Conceptions of Class Structure.
}

\author{
Wright, Erik Olin.
}

Cita:

Wright, Erik Olin (1980). Varieties of Marxist Conceptions of Class Structure. Politics \& Society, 9 (3), 323-370.

Dirección estable: https://www.aacademica.org/erik.olin.wright/40 ARK: https://n2t.net/ark:/13683/paqp/C17 abierto. Acta Académica fue creado para facilitar a investigadores de todo el mundo el compartir su producción académica. Para crear un perfil gratuitamente o acceder a otros trabajos visite: https://www.aacademica.org. 


\title{
Varieties of Marxist Conceptions of Class Structure
}

\author{
ERIK OLIN WRIGHT
}

IT has often been remarked that while class is perhaps the pivotal concept within Marxist theory, Marx himself never provided a systematic definition of class. The one chapter in Capital devoted to such an analysis breaks off after only two pages. There are numerous passages elsewhere in Capital, and in other works, where Marx does present many of the elements of a rigorous definition of class, but nowhere does there appear a sustained theoretical discussion in which all these elements are linked together into a general definition.

In recent years, as part of the general attempt by Marxist theorists to clarify rigorously the conceptual foundations of Marxism, there has been considerable effort placed on developing a more precise and systematic understanding of the concept of class. This essay will explore one central aspect of these discussions: the alternative ways in which contemporary Marxists have conceptualized the class structure of advanced capitalist societies. The premise of the analysis is that class structure is a pivotal determinant of social conflict and that therefore an adequate conceptualization of class structure is essential for a correct theory of social change. ${ }^{1}$

The disagreements over how to conceptualize class structure typically take the form of debates over how to define specific classes in capitalist society. Such definitional arguments often have an extremely scholastic air about them. Intense passion seems to be devoted to nuances of interpretation and specification. Often the criteria for adequacy of one definition over another revolve around faithfulness to classic texts rather than capacity to understand the world. And

1. This is not to suggest in the slightest that a theory of class structure is the only essential basis for a theory of social conflict and social change. The claim is simply that without a rigorous account of the structure of class relations, such a theory would be radically incomplete. 
rather than by the social relations of exchange. This third element sharply distinguishes Marxist conceptions of class from various Weberian notions. ${ }^{6}$ Within Weberian conceptions, classes are above all defined by their "market capacity," by the resources they bring into exchange relations. Marxists, however, see class relations as above all structured by the social relations within the production process itself. ${ }^{7}$ This is not to suggest that exchange relations are irrelevant but rather that their theoretical relevance is itself determined by the social relations of production.

Taking these various elements together, within the broad family of Marxist theories classes can be succinctly defined as common positions within the social relations of production. ${ }^{8}$ While all Marxists may more or less formally agree with this general definition of classes, there is very little agreement on the precise theoretical content of the notion of "social relations of production." As a result there is very little general consensus on the theoretical criteria for specific classes within the class structure of capitalist societies. Indeed, there is not even agreement among Marxists on precisely what are the classes of contemporary capitalism.

In these debates over class structure, the analysis of those positions commonly referred to as "middle class" has played a particularly pivotal role. All Marxists agree that manual, industrial wage laborers belong to the working class; and all equally agree that the owners of family enterprises belong in the capitalist class. Where the disagreement

6. Weber's classic statement on the definition of class appears in the essay "Class, Status and Party," in Economy and Society, ed. Gunther Roth (New York: Bedminster Press, 1968; originally published, 1922). More recent treatments derived from Weber's work would include: Norbert Wiley, "America's Unique Class Politics: The Interplay of Labor, Credit and Commodity Markets," American Sociological Review, vol. 32 (August 1967); Anthony Giddens, The Class Structure of the Advanced Societies (New York: Harper \& Row, 1973); and Frank Parkin, Class Inequality and Political Order (New York: Praeger, 1971).

7. The expression social relations of production is often used interchangeably with the expresssion relationship to the means of production. If the latter is taken to simply define the relationship between people and things, then it is quite different from the Marxist notion of social relations of production, which defines above all the social relations between different categories of people within the production process (particularly the relationship between exploiters and exploited).

8. It is important to note that this is a definition of "class-in-itself," that is, of class understood as a structure of positions that are filled by people. The ultimate objective of Marxist theory, of course, is not simply to describe the structure of "empty places" in a society, but to understand the conditions for the formation of those places into classes as historical, dynamic, social forces. See Adam Przeworski, "Proletariat into Class: The Process of Class Formation from Karl Kautsky's The Class Struggle to Recent Controversies," Politics \& Society, vol. 7, no. 4 (1977). This essay, however, will focus on the problem of definitions of class structure, of class-in-itself, since any analysis of class formation implicitly or explicitly presupposes an analysis of class structure. 
lies is in the analysis of white-collar employees, technical and professional positions, and various types of managers. Four general strategies for dealing with these kinds of positions have emerged in the recent debates.

One strategy is to place virtually all of these positions in the working class. Except for a very small proportion of top managers and executives, who are directly tied to the bourgeoisie by actually owning capital (stocks), all wage laborers are workers. We will refer to this as the simple polarization view of the class structure of advanced capitalism. In this perspective there are three classes in capitalist societies: a mammoth working class (80-90 percent of the population), a small petty bourgeoisie (independent self-employed producers, perhaps 8-10 percent of the population), and a tiny capitalist class.

Another strategy places many categories of wage earners into a segment of the petty bourgeoisie, often referred to as the "new petty bourgeoisie" to distinguish it from the traditional petty bourgeoisie of artisans, shopkeepers, and independent professionals. The class structure of capitalist societies is thus characterized by a moderately large working class, a petty bourgeoisie divided into two unequal segments, and a small capitalist class.

A third alternative is to consider those wage earners who fall outside the working class not as a segment of the petty bourgeoisie but rather as a new class in its own right, called the "Professional and Managerial Class" (PMC). This class is defined by the specific function it plays in the reproduction of class relations rather than simply its position within the social relations of production as such.

Finally, it is possible to argue that not all positions within the production process will fall unambiguously into a single class location. In this view, some positions occupy what can be termed "contradictory locations within class relations," locations that are objectively torn between classes. Many of the positions commonly labeled "middle class" occupy such contradictory locations. There are two versions of this general stance toward class structure: a version that analyzes contradictory locations primarily in terms of the performance of contradictory functions within the production process; and a version that analyzes these locations in terms of contradictory structural relations of domination and subordination within production. The distinction between these two versions will become clearer in the course of the discussion.

Before proceeding with the analysis of these four clusters of definitions, it is important to say a word about my personal relationship to these debates. I am a committed partisan within the current Marxist 
debates on class structure. Much of my research and writing has involved the elaboration and defense of the structural-relations version of the fourth perspective on class structure listed above. While I shall try to be as fair and accurate as possible in my discussion of the various other positions, my account is not an "innocent" one, to use Louis Althusser's expression. The exposition and critique of each of the other perspectives on class structure that will be discussed is thus from a particular vantage point within the debate itself. It will, therefore, be helpful to begin the discussion by laying out this vantage point; I shall then turn to a detailed discussion of the various other general perspectives on class structure within contemporary Marxism.

\section{CONTRADICTORY LOCATIONS WITHIN CLASS RELATIONS: STRUCTURAL VERSION}

The general outlines of the theory of contradictory locations within class relations were first presented in an essay in the New Left Review in 1976 and later elaborated in a series of other publications. ${ }^{9}$ The basic argument revolves around an analysis of three interconnected dimensions of domination and subordination within production. Each of these dimensions involves a social relation of domination and subordination with respect to some particular resource within production: money capital, that is, the flow of investments into production and the direction of the over-all accumulation process (accumulation of surplus value); physical capital, that is, the actual means of production within the production process; and labor, that is, the laboring activity of the direct producers within production. ${ }^{10}$ These

9. The initial formulation was in Erik Olin Wright, "Class Boundaries in Advanced Capitalist Societies," New Left Review, no. 98 (1976), pp. 3-41. This essay was then revised as chap. 2 in Class, Crisis and the State (London: New Left Books, 1978). Other discussions of contradictory locations include: idem, "Intellectuals and the Working Class," The Insurgent Sociologist, Summer 1978; idem, Class Structure and Income Determination (New York: Academic Press, 1979); and idem, "Class, Occupation and Organization," International Yearbook of Organizational Theory, vol. 1, ed. David Dunkerley and Grahem Saleman (London: Routledge and Kegan Paul, 1979). For some critical remarks on the analysis of contradictory locations, see Edward S. Greenberg and Thomas F. Mayer, "Review of Class, Crisis and the State," Kapitalistate, no. 7 (1979), pp. 167-86; and Barbara Ehrenreich and John Ehrenreich, "Rejoinder," in Between Capital and Labor, ed. Pat Walker (Boston: South End Press, 1979), esp. pp. 325, 331-32.

10. It should be noted that the actual resource in production is "labor," not "labor power." Labor power is a commodity purchased on the labor market. It represents the potential capacity for labor within production. Labor is the actual activity of work within the production process. The key issue in the social relations of production is the domination and subordination within the labor process itself, that is, the relations of control over the actual deployment and activity of labor. 
relations can be characterized as relations of domination and subordination because each relation simultaneously defines those positions that have the capacity to control the particular resource and those that are excluded from such control. The first of these dimensions is often referred to as "real economic ownership"; the second and third together are often referred to as "possession."11

In no sense should these three dimensions be thought of as three independent types of relations. Within capitalist production they are each necessary conditions for the existence of the others; there is no sense in which they can exist autonomously. Nevertheless, while these three dimensions of social relations are intrinsically interdependent, there is still a clear hierarchy of determination among them. The social relations of control over money capital structure, or set limits upon, the relations of control over physical capital, which in turn limit the direct control over labor within production. A rentier capitalist, therefore, who is not directly involved in control over physical capital or labor, nevertheless falls within the capitalist class because of the social relations of control over money capital ("real economic ownership" of the means of production).

The fundamental class relation between labor and capital can be thought of as a polarized, antagonistic relation along all three of these dimensions: The capitalist class occupies the dominant position with respect to the social relations of control over money capital, physical capital, and labor; the working class occupies the subordinate position within each of these dimensions of social relations.

When the class structure is analyzed at the highest level of abstraction-the level of the "pure" capitalist mode of production-these are the only two classes defined by these three dimensions of relations of production. When we move to a lower level of abstraction-the level of what Marxists call the "social formation"-other classes enter the analysis. This occurs for two basic reasons. First, concrete capitalist social formations are never characterized simply by the capitalist mode of production. Various kinds of precapitalist relations of production exist side by side with capitalist relations, although typically these are of marginal importance and are socially subordinated in various ways to the capitalist mode of production. Of particular importance in these terms is simple commodity production: the production and sale of goods by self-employed individuals who employ no workers.

11. For a discussion of the concepts of economic ownership and possession, see Etienne Balibar, "The Basic Concepts of Historical Materialism," in Louis Althusser and Etienne Balibar, Reading Capital (London: New Left Books, 1970). 
In terms of the three dimensions of social relations of production discussed above, such "petty bourgeois" class locations involve control over money capital and physical capital but not over labor (since no labor power is employed within production).

The second way in which additional class locations appear when we study class structures within concrete capitalist societies is that the three dimensions of social relations of production need not necessarily coincide perfectly-indeed, there are systemic forces in capitalist development working against their doing so. Such noncorrespondence generates what I have termed "contradictory locations within class relations." Three such contradictory locations are particularly important.

Managers and supervisors occupy a contradictory location between the working class and the capitalist class. Like the working class they are excluded from control over money capital (that is, from basic decisions about allocation of investments and the direction of accumulation), but unlike workers they have a certain degree of control of the physical means of production and over the labor of workers within production. Within the manager-supervisor contradictory location, top managers occupy the position closest to the capitalist class, whereas foremen occupy the location closest to the working class.

Small employers occupy a contradictory location between the petty bourgeoisie and the capitalist class proper. Unlike the petty bourgeoisie, they do employ some labor power and thus are in a relation of exploitation with workers. But unlike the capitalist class, they are themselves directly engaged in production alongside their workers, and they do not employ sufficient quantities of labor power to accumulate large masses of capital.

Semiautonomous employees occupy a contradictory location between the petty bourgeoisie and the working class. Like the working class, they are excluded from any control over money capital and the labor of others, but like the petty bourgeoisie they do have some real control over their immediate physical means of production, over their direct activity within the labor process. These three contradictory locations are schematically represented in the accompanying figure and in a more formal way in table 1.

It should be noted that in table 1 there is more than one position (or "level") within each of the three dimensions of social relations of production. Take, for example, the social relations of control over physical capital, one of the two aspects of "possession" of the means of production. "Full" control in this instance implies that the position is involved in decisions concerning the operation and planning of the 

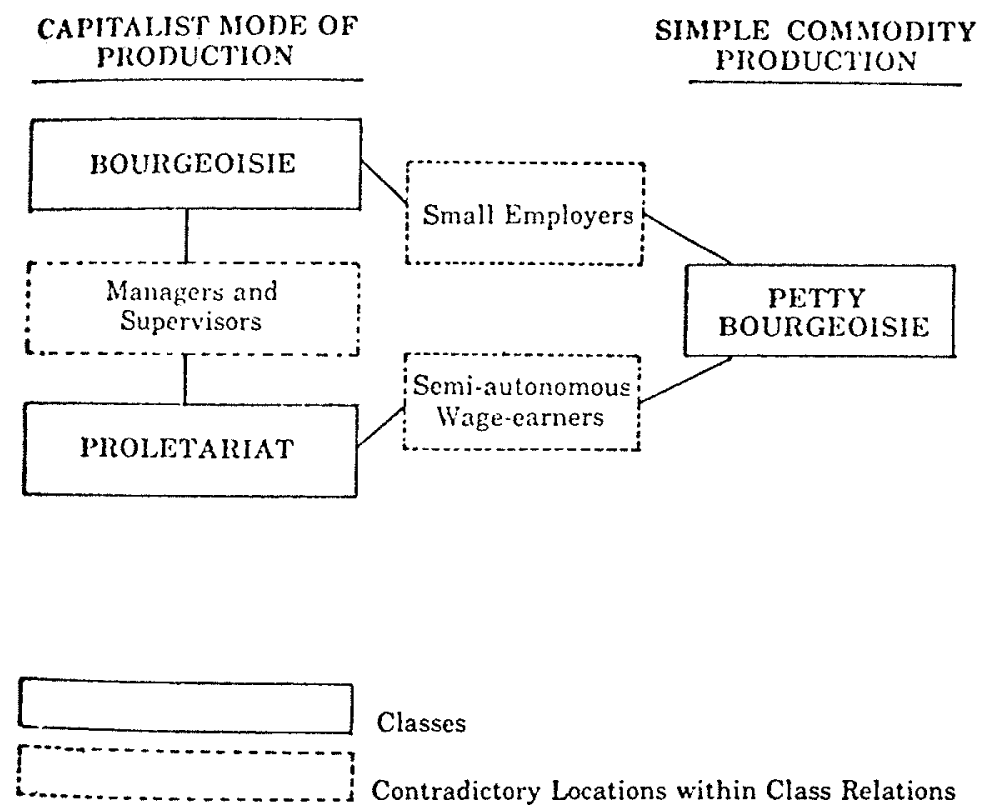

The Basic Class Relations of Capitalist Society

entire production process; "partial" control implies participation in decisions concerning specific segments of the production process; "minimal" control implies control over one's immediate means of production within the labor process; "no" control implies complete exclusion from decisions concerning the operation of the means of production. Each of these "levels" of control must be understood in terms of the social relations with other levels; they are not simply points on a scale. Taken together, they make it possible to identify more precisely specific positions within each contradictory location.

It is important to understand the precise sense in which these class locations are "contradictory" locations within class relations. They are not contradictory simply because they cannot be neatly pigeonholed in any of the basic classes. The issue is not one of typological aesthetics. Rather they are contradictory locations because they simultaneously share the relational characteristics of two distinct classes. As a result, they share class interests with two different classes but have interests identical to neither. It is in this sense that they can be viewed as being objectively torn between class locations. 


\begin{tabular}{|c|c|c|c|c|}
\hline \multirow[b]{2}{*}{ Class Positions } & & \multicolumn{3}{|c|}{ Dimensions of social relations of production } \\
\hline & & $\begin{array}{l}\text { Relations of } \\
\text { Economic Owmership } \\
\\
\text { Control over } \\
\text { money capital }\end{array}$ & $\begin{array}{l}\text { Relations of } \\
\text { Control over } \\
\text { physical } \\
\text { capital }\end{array}$ & $\begin{array}{l}\text { ssession } \\
\text { Control } \\
\text { over } \\
\text { labor }\end{array}$ \\
\hline \multirow[t]{2}{*}{ Bourgeolsie } & $\begin{array}{l}\text { Traditional } \\
\text { capitalist }\end{array}$ & + & + & + \\
\hline & $\begin{array}{l}\text { Top corporate } \\
\text { executive }\end{array}$ & + & + & + \\
\hline \multirow{4}{*}{$\begin{array}{l}\text { Contradictory class } \\
\text { location between the } \\
\text { bourgeoisie and the } \\
\text { prolecariat }\end{array}$} & Top managers & Partial/minimal & + & + \\
\hline & Middle managers & Minimal/- & Parcial & Partial \\
\hline & Technocrats & - & Minimal & Minimal \\
\hline & Foremen/supervisors & - & - & Mininal \\
\hline Proletariat & & - & - & - \\
\hline $\begin{array}{l}\text { Contradictory class } \\
\text { location between the } \\
\text { proletariat and the } \\
\text { petty bourgeoisie }\end{array}$ & $\begin{array}{c}\text { Semiautonomous } \\
\text { employees }\end{array}$ & - & Mininal & 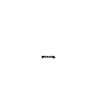 \\
\hline Petty Bourgeoisie & & + & + & - \\
\hline $\begin{array}{l}\text { Contradictory class } \\
\text { location between the } \\
\text { petty bourgeoisie } \\
\text { and the bourgeolsie }\end{array}$ & Small employers & + & + & Minimal \\
\hline
\end{tabular}

NOTE: $+=$ Full control; - = no control

Levels of control within each dimension of production relations may be defined, schematically, as follows:

Relations of Economic Ownership

Full control

Partial control

Mininal control

No control production
Control over the overall investment and accumulation process

Participacion in decisions concerning either subunits of the total production process or partial aspects of the entire investment process

Participation in decisions concerning narrow aspects of subunits of

Complete exclusion from participation in investment and accumulation decisions

Relations of Possession

Control of Means
of Production Control of Labor

Control over the entire apparatus of production

Control over one segment of the total production process

Control over one's immediate instruments of production; some autonomy in the immediate labor process

Negliglble control over any aspect of the means of production
Control over the entire supervisory hierarchy

Control over one segment of the supervisory hierarchy

Control over the direct producers, over immediate subordinates, but not part of the hierarchy as such

No ability to invoke sanctions on other workers 
The schema represented in the figure on page 307 and table 1 is not without its difficulties. While it does provide a fairly comprehensive way of locating positions within the social relations of production, there is a degree of arbitrariness involved in trying to define precisely the boundaries of each of these contradictory locations. On the one hand, at a certain point, supervisors become mere conduits for information from above and lose any capacity for actually controlling the labor of subordinates. Such nominal supervisors should be considered part of the working class. As top managers shade into top executives, on the other hand, and begin to participate in the control of basic investment decisions, then they should be placed within the bourgeoisie proper. Similar problems are encountered in defining the "boundaries" of the semiautonomous-employee location and the small-employer category.

Furthermore, in the case of semiautonomous employees there is a real ambiguity in the very content of the "autonomy" that defines the contradictory class location. Does the possession of specialized skills or knowledge constitute control over the immediate labor process? Does one have to have some control over what is produced as well as how it is produced? Is the issue autonomy vis-à-vis supervisors per se, or is it autonomy with respect to concrete tasks?

Finally, the schema as represented above only includes positions directly engaged in production. Positions located outside immediate capitalist production-state employees, housewives, pensioners, students, and so forth-are not directly defined by the criteria. Are these positions in some sense "outside" the class structure, or are they situated within class relations through social relations other than production relations? Elsewhere I have offered a provisional solution to this problem. ${ }^{12}$

These and other issues are still in the process of resolution. It may well be that in the course of adequately solving these problems, the basic schema itself will undergo substantial modification. It is precisely through such a process of "theoretical practice," to use the Althusserian expression, that concepts are transformed. For the moment, however, the schema in the figure on page 307 and table 1 constitutes the basic framework within which contradictory locations within class relations can be analyzed.

Let us now turn to alternative ways of viewing the class structures of capitalist societies and evaluate them in terms of this conceptualization. Class."

12. See Class, Crisis and the State, chap. 2; and idem, "Intellectuals and the Working 


\section{SIMPLE POLARIZATION VIEW OF CLASS STRUCTURE}

The classic statement of the view that the class structure of advanced capitalist societies should be seen as a simple polarization between the bourgeoisie and the proletariat is found in the Communist Manifesto: "Our epoque, the epoque of the bourgeoisie, possesses, however, this distinctive feature: it has simplified the class antagonisms. Society as a whole is more and more splitting up into two great hostile camps, into two great classes directly facing each other: Bourgeoisie and Proletariat." The "middle class," in such a view, consists only of small shopkeepers, farmers, and other traditional petty bourgeois. As capitalism advances, the proportion of the population engaged in self-employed, petty bourgeois production declines steadily, and the class structure becomes ever more polarized between workers and capitalists. The formal criteria for classes in such a view are presented in table 2.

A number of contemporary writers have defended this view. Charles Loren defines classes in general as "groups of people which, owing to their different relations to the means of production, differ in relation to the surplus labor of society, generally either providing it to another group, disposing of the surplus labor of another group, or disposing only of its own surplus labor." Except for top executives, all employees regardless of their function in production "provide" surplus labor to capital and thus belong in the working class. As a result, Loren estimates that approximately 90 percent of the U.S. population is working class, 8 percent petty bourgeois producers, and 2 percent capitalist class. ${ }^{13}$

TABLE 2

Simple Polarization View of Class Structure

\begin{tabular}{lccc}
\hline \hline & $\begin{array}{c}\text { Owns Means of } \\
\text { Production (Income } \\
\text { from Property) }\end{array}$ & $\begin{array}{c}\text { Purchases } \\
\text { Labor Power }\end{array}$ & $\begin{array}{c}\text { Sells Labor } \\
\text { Power (Income } \\
\text { from Wages) }\end{array}$ \\
\hline $\begin{array}{l}\text { Capitalists } \\
\begin{array}{l}\text { Traditional Petty } \\
\text { Bourgeoisie }\end{array}\end{array}$ & + & + & - \\
\begin{tabular}{l} 
Proletariat \\
\hline
\end{tabular} & - & - & + \\
\hline
\end{tabular}

NOTE: $+=$ yes; $-=$ no.

13. Charles Loren, Classes in the United States (Davis, Calif.: Cardinal Publishers, 1977), pp. 9,32 . 
James Becker and Francesca Freedman both adopt a similar view. ${ }^{14}$ They argue that while the transformations of the technical division of labor in the course of capitalist development may have generated new divisions or strata within classes, these divisions have not in any way altered the structure of class relations in the capitalist mode of production. Freedman writes:

The creation by capitalism of new functions and occupations-through the progressive development of the forces of production, as well as by the expansion of capital into new fields-does not mean a change in the basic economic relations between classes. Hence, it does not give rise to new classes within capitalism. Rather, it gives rise to new fractions within classes, grouped around different forms of economic activity or around the place occupied within these activities.... On the one hand, the expansion of capital necessitates divisions within the working population, corresponding to the creation of new use-value functions for labor. On the other hand, this labor is unified under the wage-relation. ${ }^{15}$

The working class is thus defined exclusively by the wage relation, the capitalist class by ownership of the means of production. Freedman is careful to give both of these criteria specific meaning. The wage relation is not simply a juridical category; rather, it reflects that the wage laborer can obtain the means of livelihood only by working for someone else. ${ }^{16}$

Similarly, "ownership of capital" does not simply refer to legal titles, but to the owner not needing to work in order to obtain income. In these terms, Freedman insists that "middle-level management is part of the working class. Although these managers may be highly paid, their income is insufficient to allow them entry into the capitalist class-i.e., they cannot own significant amounts of corporate stock or other financial assets." At the very top levels of the managerial hierarchy, however, managers must be included within the bourgeoisie proper: "Ultimately the distinction hinges on accessibility to capital and capital-earnings (to such a degree that they can form the bulk of income), where a quantitative increase in income must be associated

14. James F. Becker, "Class Structure and Conflict in the Managerial Phase," pts. 1, 2, Science \& Society, vol. 37, no. 3 (Fall 1973) and vol. 37, no. 4 (Winter 1973-74); and Francesca Freedman, "The Internal Structure of the Proletariat: A Marxist Analysis," Socialist Revolution, no. 26 (1975).

15. Freedman, "Internal Structure of the Proletariat," pp. 43-45.

16. Freedman defines the wage relation in the following terms: "The wage-relation has been termed 'juridical'-and so it is, if viewed from the perspective of the wage-contract between capitalists and workers. On this level it is the exchange of equivalents: wages in return for the sale of labor-power. However, this juridical aspect, where the worker is 'free' to contract with the capitalist, is merely the reflection of a more essential foundation: the fact that the worker is 'free' of any other means of production and hence must work for the capitalist. It is in this sense that I use the word "wage-relation.' "Ibid., p. 49n. 
with a qualitative change in class membership. This point is reached when the exchange-value of labor and occupational position allow for the purchase of stock or other forms of capital to a significant degree." 17 While there may be a few positions that are ambiguous and difficult to classify in these terms, in principle everyone who is not a traditional petty bourgeois is thus either a worker or a capitalist.

The most sophisticated and sustained defense of a simple polarization view of the class structure of advanced capitalist societies appears in a recent book by Anthony Cutler, Barry Hindess, Paul Hirst, and Athar Hussain. ${ }^{18}$ Their argument hinges upon an analysis of the distinction between the social division of labor and the technical division of labor. The former is defined by what the authors term the "mode of possession and of separation" with respect to the means of production: ". . . The modes of possession and of separation and the forms of what is effectively possessed distinguish different types of classrelation. In all cases, however, effective possession involves a capacity to control the functioning of means of production in the process of production and to exclude others from their use."19 The technical division of labor, however, consists of "the division of functions technically necessary to an economy," where "technically necessary" is understood in the broadest possible way to mean all activities directly or indirectly contributing to production. ${ }^{20}$

Classes, in Cutler et al.'s analysis, are defined solely by the mode

17. Ibid., pp. 65,66 .

18. Anthony Cutler, Barry Hindess, Paul Hirst, and Athar Hussain, Marx's Capital and Capitalism Today, vol. 1 (London: Routledge \& Kegan Paul, 1977). This book is one work in a larger project of reconstruction of Marxist theory begun by Barry Hindess and Paul Hirst. The earlier works that form the background of the Cutler, Hindess, Hirst, and Hussain volume are Hindess and Hirst, Precapitalist Modes of Production (London: Routledge and Kegan Paul, 1975); and idem, Modes of Production and Social Formation (London: Routledge and Kegan Paul, 1977). The Cutler et al. book has subsequently been followed by a second volume with the same title (1978).

19. Cutler, et. al., Capitalism Today, vol. 1, p. 249. As a point of terminological clarifiction, it should be noted that Cutler et al. give the term possession a meaning rather like that given economic ownership by writers such as Poulantzas and Balibar. As mentioned in the discussion of contradictory locations above, economic ownership refers to control over the flow of resources into and out of production, that is, the capacity to dispose of the product and control the investments that result from the sale of the product (profits). Possession, in Balibar's usage, refers to the immediate capacity to set in motion the means of production. Capitalists, in these terms, have both possession and ownership of the means of production. Cutler et al. have altered this usage and argue that possession alone ("economic ownership" in Balibar's terminology) defines the capitalist class. Throughout this discussion of Cutler et al.'s position I shall adopt their terminology so that the text corresponds to the quotations from their work.

20. Ibid., p. 255. 
of possession of and separation from the means of production. To be separated from the means of production in a capitalist society implies that the "agent" of production must sell his or her labor power as a commodity in order to work. To possess the means of production implies being able to set the means of production into motion without selling one's labor power. In effect, therefore, in their analysis, all employees in capitalist enterprises, including the top executives of monopoly corporations, fall into the working class. Employees outside of capitalist production, such as state civil servants, neither possess nor are separated from the means of production and therefore occupy no class position at all. They are "outside" of economic class relations altogether.

Who are the capitalists, then? Capitalists are defined as those agents of production who have legal ownership of the means of production and have the capacity to dispose of the means of production as they wish. In monopoly capitalism, it is generally the corporation itself, as an organization, that occupies the capitalist position. In advanced capitalism it is therefore entirely possible in their analysis to have a capitalism without any human individuals being capitalists.

This entire argument hinges on the claim that managerial functions, even those performed by the presidents of corporations, must simply be considered specialized technical functions carried out by an elite stratum of the working class. While top managers do perform functions directly delegated by capital, and indeed they may make decisions that are binding on the company (that is, "capital") as a whole, nevertheless, since production in capitalist society would be impossible without the performance of these managerial activities they have to be considered technical requirements of production. "No amount of the performance of the function of direction" they write, "confers on the manager the capacity to alienate or appropriate the means of production in question, or even the right to continue to exercise the function of direction." Managers, even corporation presidents, can be fired, and this decisively demonstrates that they do not genuinely possess the means of production, regardless of how much power is delegated to them by the enterprise. Capitalists are not fired; they go bankrupt. Thus, Cutler et al. conclude, "capital controls its managers," even the managers at the apex of the authority structure. ${ }^{21}$ Even though "capital" in the case of monopoly capitalism is a nonhuman corporation, the highest executives in that corporation, like the assembly-line workers, are separated from the means of production and thus are part of the proletariat. 


\section{Critique}

The central problem in all of these simple polarization accounts of the class structure lies in the definition of the "social" relations of production and particularly in the distinction made between the social and technical aspects of production. That certain activities are functionally necessary for production to take place in capitalist society does not imply that they can be treated as purely technical functions. Given that production takes place within an antagonistic set of class relations, there are necessary social functions as well as technical functions for production to take place. Among these are the exclusion of workers from the direction of investments, from planning the use of the physical means of production, and from control of labor itself. Of course, all of these activities do have purely technical aspects to them, but they also constitute basic dimensions of the social relations of production.

Cutler et al. correctly define possession of the means of production as "the capacity to control the functioning of the means of production," but they then procede to treat the actual activity of directing the means of production (as opposed to the capacity to control the direction) as a "technical" function distinct from possession. This is an essentially arbitrary distinction. While it does make sense to distinguish participation in decisions from mere execution of decisions, there is little sense in distinguishing the capacity to control decisions from actual participation in the making of decisions. Top executives and directors of corporations may be fired, but they are fired by collectivities of other directors and top executives, collectivities in which they are participating members. The social mechanisms by which they lose their jobs are thus qualitatively different from the mechanisms by which workers lose their jobs. They may not personally possess the means of production as individuals, but they are members of collectivities that do possess those means of production.

Cutler et al., and other theorists who defend the simple polarization view of the class structure, are quite correct in arguing that managers who are not top executives should not be included in the capitalist class. But it does not follow from this that they belong in the working class. If the relations of production are understood as a complex structure of interconnected dimensions of relations, then workers cannot be defined simply as those who cannot appropriate the means of production; workers also cannot control the conditions of their own work and that of others. Since most managers do have some degree of control, they fall neither into the working class nor into the bourgeoisie. It is precisely for this reason that the concept of "contradictory locations within class relations" was introduced. 
In the end, the claim that all wage earners are members of the working class obscures fundamental-not marginal or secondarydivisions among wage earners. If class as a concept is to explain anything it must provide the basis for explaining class struggles, the formation of people into classes as organized social forces. The designation of a set of positions in a social structure as common "class" positions (as opposed to some other sort of position) is, in a sense, a proposition about the potential unity of such positions within the class struggle. And this, in turn, is based on an implicit proposition that such positions share fundamental class interests, that is, interests defined at the level of modes of production. ${ }^{22}$

The category of all wage earners is far too heterogeneous in its basic interests to provide a structural basis for class formation. It is simply implausible to claim that top managerial positions are part of the proletariat, having class interests fundamentally identical to those of industrial workers and fundamentally opposed to those of capitalists. Even if, following Cutler et al., we were to see corporations as such occupying the position of "capital" in the class structure, nevertheless the interests of top executives, however defined, would clearly be much closer to the interests of the corporations than of the manual workers within them.

Simple polarization conceptions of the class structure of contemporary capitalist societies are therefore inadequate because: (1) they reduce the social relations of production to a one-dimensional relation of possession or economic ownership; (2) they tend to identify as technical functions activities that should properly be thought of as aspects of the social relations of production; and (3) they break the relationship between the analysis of class structure and class formation by including within the working class social positions with fundamentally opposing class interests.

\section{CONCEPTIONS OF CLASS STRUCTURE IN TERMS OF THE NEW PETTY BOURGEOISIE}

Perhaps the most popular general solution among Marxists to the

22. Fundamental interests are to be contrasted with immediate interests, defined as interests that take the mode of production as a given. The immediate interests of workers, for example, are defined largely by market conditions (by the terms of the sale of the commodity labor power). In terms of immediate interests, the working class is internally quite divided. Fundamental interests, however, call into question the mode of production (dominant relations of production) itself. At this level, the working class has a common interest in socialism, that is, in the transformation of capitalist relations of production into socialist relations of production (relations in which the working class controls the means of production). For a discussion of fundamental and immediate interests, see Wright, Class, Crisis and the State, pp. 88-91. 
problem of locating various professional, technical, and managerial employees within the class structure is to place them within the diffuse class category "petty bourgeoisie" (sometimes also referred to, even more loosely, as the "middle class"). Typically, these categories of wage earners are called the "new" petty bourgeoisie in order to distinguish them from the traditional petty bourgeoisie of shopkeepers and artisans.

Three different versions of this thesis have appeared in recent discussions: In the first version, skilled intellectual laborers, especially when they possess academic credentials, are considered to be petty bourgeois because they "own" their intellectual skills in a way analogous to the ownership of small property by the traditional petty bourgeoisie. In the second version, all unproductive wage earners are considered to be new petty bourgeois. Finally, in the third, all wage earners whose income is above the value of their labor power (that is, whose income contains a component of redistributed surplus value from other workers) are considered to be new petty bourgeois, regardless of whether they are technically productive labor or unproductive labor.

I shall discuss and comment upon each of these stances in turn.

\section{Skills, Credentials, and the New Petty Bourgeoisie}

The first of these positions is not widely argued among Marxists. The most systematic attempt to make this argument that I know of is by Judah Hill. ${ }^{23}$ Hill argues that intellectuals "own" their intangible intellectual knowledge, especially when such knowledge is legally validated through credentials. Such intellectual skills are thus seen as a form of "property" enabling the possessor of that property to obtain a variety of special privileges, especially income privileges. Because intellectuals are property owners who do not employ other workers, they fall into the same class as the traditional petty bourgeoisie.

\section{Critique}

This argument has several critical weaknesses. First of all, it transposes the basic criteria of class from the social relations of production to the social relations of exchange. The claim that skills and credentials constitute a special form of property comes very close to Weber's and

23. Judah Hill, Class Analysis: The United States in the 1970s (Emeryville, Calif.: Class Analysis, P.O. Box 8494. 1975). 
Giddens's arguments that it is market capacity that defines class location. Of course, it can happen that the possession of certain skills also creates a certain degree of control or autonomy within the labor process itself. When this occurs, then there would be a basis for claiming that the wage earner who has skills and credentials fell outside the working class. But even then it is not the skill per se or the possession of a credential per se that defines the class location, but rather the actual production relation associated with that skill or credential. Many workers with considerable skills and credentials essentially lose all control over their labor once they enter the employment relation and thus should be considered fully proletarianized.

Secondly, even if we were to grant that intellectual skills were a kind of "property," this would not be sufficient to place intellectual wage earners in the petty bourgeoisie. Skills constitute a qualitatively different kind of property, reflecting qualitatively different social relations, from physical property of whatever form. Skills cannot be dispossessed, they cannot be used as collateral, they cannot be sold (the capacity to perform skilled labor can be sold, but not the skills as such). The result is that a skilled, credentialed intellectual enters into qualitatively different social relations of production from that of the traditional petty bourgeoisie, even if it is the case that the intellectual retains substantial control over his or her immediate labor process. To obliterate these differences by placing intellectual wage earners into the same class as the petty bourgeoisie is to obscure the contours of the class structure, not to clarify them. I shall return to this issue in discussing the other versions of new petty bourgeoisie conceptions of the class structure.

\section{Unproductive Labor and the New Petty Bourgeoisie}

The concept of "unproductive labor" is a complex one within Marxist theory and is currently the subject of considerable debate in a number of different contexts. ${ }^{24}$ The basic idea is that certain categories of wage earners, while employed by capital, nevertheless do not produce any surplus value. Surplus value, it will be recalled, consists of labor time embodied in commodities beyond the costs of reproducing the labor power of the worker (referred to as the value

24. For discussions of unproductive labor see Wright, Class, Crisis and the State, pp.4650; James O'Connor, "Productive and Unproductive Labor", Politics \& Society, vol. 5, no. 3 (1975); and Ian Gough, "Productive and Unproductive Labor in Marx", New Left Review, no. 76 (1972), pp. 47-72. 
of the workers' labor power). The simplest situation in which no surplus value is produced is in capitalist firms in which no commodities are produced. A good example is a bank, where all of the activities revolve around financial exchanges and property rights, but not around the actual production of commodities. If no commodities are produced, no value is created, and if no value is created, no surplus value is created. As a result, all bank employees are unproductive. More generally, wage earners whose activities are confined to the sphere of exchange of commodities are unproductive. A cashier in a grocery store, for example, is unproductive since his or her activity is simply involved in the transfer of property rights (sale of commodities). The truck drivers and warehouse workers who transport the food and place it on the shelves, however, are productive, since their activity involves the physical transformation of the commodity itself (its transportation through space) and is thus part of the production process.

The basic logic of the claim that unproductive laborers are part of the new petty bourgeoisie is that although they are employed by the bourgeoisie, their livelihood comes out of the surplus value produced by productive workers, since they themselves produce no value at all. Thus, in a sense, they live off the labor of the working class. Such unproductive labor, it is sometimes argued, would thus have a stake in increasing the rate of exploitation of productive workers, since this would increase the pool of surplus value available for redistribution to them in the form of wages. It is this that places them in an intermediate position between the proletariat and the bourgeoisie. The basic schema of this argument is illustrated in table 3 .

TABLE 3

Unproductive Labor and the New Petty Bourgeoisie

\begin{tabular}{lcccc}
\hline & $\begin{array}{c}\text { Owns Means of } \\
\text { Production }\end{array}$ & $\begin{array}{c}\text { Purchases } \\
\text { Labor } \\
\text { Power }\end{array}$ & $\begin{array}{c}\text { Sells } \\
\text { Labor } \\
\text { Power }\end{array}$ & $\begin{array}{c}\text { Produces } \\
\text { Surplus } \\
\text { Value }\end{array}$ \\
\hline $\begin{array}{l}\text { Capitalists } \\
\begin{array}{c}\text { Traditional Petty } \\
\text { Bourgeoisie }\end{array}\end{array}$ & + & + & - & - \\
$\begin{array}{c}\text { New Petty } \\
\text { Bourgeoisie }\end{array}$ & - & - & - & - \\
$\begin{array}{c}\text { Proletariat } \\
\text { Class }\end{array}$ & - & - & + & + \\
\hline
\end{tabular}

NOTE: $+=$ yes; $-=$ no. 
Martin Nicolaus presents one version of this perspective. Nicolaus structures his argument around Marx's analysis in Capital of the laws of motion that govern capital accumulation. The key thesis is that as capitalism expands, an increasing proportion of the population must be employed in unproductive activities, for two basic reasons. First, a great deal of unproductive labor is technically necessary in the accumulation process:

As productivity rises, the number of unproductive laborers required to service and maintain the growing capital establishment also rises. The number of the traditional unproductive workers increases, e.g., clerks, bookkeepers. More significantly, entirely new branches of unproductive work are called into being, of which the banking system, the credit system, insurance empires and advertising are the most obvious examples, but the growth of the scientific and technological establishments, as well as an increase in public education generally, are also in this category.

Second, as productivity increases, the mass of surplus value increases (even though the rate of profit may decline). In order for capital accumulation to continue, this surplus value must be realized. If it is not, the result is a serious underconsumption crisis. The expansion of the ranks of unproductive labor is one of the essential ways that such underconsumption tendencies are mitigated. The result of these two requirements of advanced capitalism-the technical need for unproductive labor and the need to absorb the surplus product-is what Nicolaus terms "the 'law of the surplus class,' that is, the law of the tendential rise of a new middle class.",25

A somewhat more complex example of this same general perspective on the new middle class is presented by John Urry who poses the problem in slightly different terms from Nicolaus. He argues that "the nature of capitalism is such that there are two sets of functions: that of capital accumulation and that of producing value or surplus value. . . . The former is the capitalist function, the latter is the function of labor." These two functions give rise to two dichotomies: ownership and nonownership of the means of production; production and nonproduction of value. Like Nicolaus, Urry then defines the new middle class as those people who are nonowners and nonproducers of surplus value. ${ }^{26}$

Urry then proceeds to discuss a series of other dichotomies that

25. Martin Nicolaus, "Proletariat and Middle Class in Marx," Studies on the Left 7 (January-February, 1967), p. 275.

26. John Urry, "Towards a Structural Theory of the Middle Class," Acta Sociologica 16, no. 3 (1973): 182. Urry defines the traditional petty bourgeoisie as people who 
differentiate people in their work situation: high status and low status; powerful and powerless; hirers and hired. These criteria also differentiate the new middle class from workers. Whereas workers have low status, are powerless, and are hired, the members of the new middle class all are either powerful or have high status and, as in the case of managers, are hirers as well-that is, they are "responsible for the hiring of labor."27 Taking all these criteria together, we get the typology of class positions illustrated in table 4.

The most thorough attempt to ground the analysis of the new middle class in the concept of unproductive labor is represented by the work of Nicos Poulantzas, especially in his two important books, Political Power and Social Class (London: New Left Books, 1973)

TABLE 4

Criteria for Class Position in Urry's Analysis

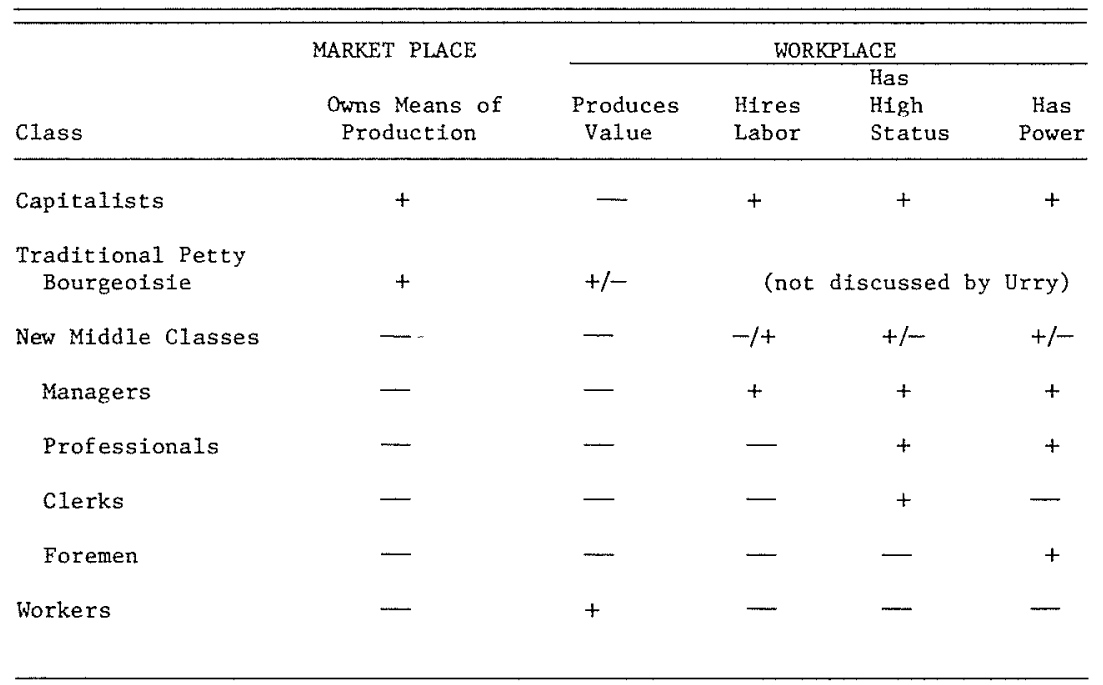

NOTE: $+=$ yes $;-=$ no $+/-=$ mostly $;-/+=$ infrequent $1 \mathrm{y}$.

own the means of production and produce value (they work in their own enterprises productively). This leads him into a problem of classifying small shopkeepers, who by his criteria would be considered capitalists (they are owners but do not produce value). The difficulty is that Urry never actually includes the capital-labor relation explicitly in the typology, and thus he is forced to differentiate capitalists and petty bourgeois on other criteria. Urry simply states by fiat that small shopkeepers are petty bourgeois without providing any explicit criteria for this classification.

27. Ibid., p. 183. 
and Classes in Contemporary Capitalism (London: New Left Books, 1975). I have made a detailed exposition and critique of his theory of class structure in Class, Crisis and the State, and here I shall only briefly summarize that discussion.

Like Nicolaus and Urry, Poulantzas argues that unproductive wage earners must be excluded from the ranks of the proletariat because they lie outside the basic, dominant capitalist relation of exploitation. In discussing commercial employees as an example of unproductive labor, Poulantzas writes: "Of course, these wage-earners are themselves exploited, and their wages correspond to the reproduction of their labor-power. 'The commercial worker ... a adds to the capitalist's income by helping him to reduce the cost of realizing surplus value, inasmuch as he performs partly unpaid labor.' Surplus labor is thus extorted from wage-earners in commerce, but these are not directly exploited in the form of the dominant capitalist relation of exploitation, the creation of surplus value." 28 The working class is defined by the fundamental class antagonism within capitalism between direct producers, who are separated from the means of production and produce the social surplus product in the form of surplus value, and the bourgeoisie, who own the means of production and who appropriate surplus value. Unproductive wage earners, while clearly not members of the bourgeoisie, do not contribute to the production of the surplus product, and are thus not directly exploited.

Poulantzas goes beyond the analyses of Nicolaus and Urry in two important respects. First, he insists that class positions cannot be defined simply at the level of economic relations; political and ideological factors must be taken into account as well. While Urry touches on such issues in his discussion of power and status in the workplace, Poulantzas integrates political and ideological relations much more systematically. Second, Poulantzas dissects the global concept of "ownership of the means of production" and breaks it down into several interconnected dimensions. This allows for a much more refined analysis of the boundary between the bourgeoisie and the new petty bourgeoisie.

When Poulantzas refers to "political relations" as a determinant of class position, he is especially concerned with relations of supervision and authority within the capitalist enterprise. "The work of management and supervision under capitalism," Poulantzas writes, "is the direct reproduction, within the process of producton itself, of the political relations between the capitalist class and the working class.",29

28. Classes in Contemporary Capitalism (London: New Left Books, 1975), p. 212.

29. Ibid., p. 227. 
In these terms, a foreman or supervisor in commodity production would be viewed as occupying a position of political domination of the working class. Such an individual would therefore be placed in the new petty bourgeoisie even if he or she engaged in productive labor in the production process.

"Ideological relations" are used by Poulantzas mainly to refer to the status division between mental and manual labor. Thus, for example, a white-collar technician occupies a position of ideological domination of the working class because of the ideological role of "expertise" within capitalist society. It is important for the reproduction of class relations in capitalism that workers believe that experts are necessary to run the productive apparatus, that the working class is incapable of organizing production on its own. Technicians and other "mental" laborers are carriers of this relation of ideological domination. Thus, Poulantzas argues, even if they do not supervise anyone and even if they are productive laborers, mental laborers should still be placed in the new petty bourgeoisie.

The distinction between the working class and the new petty bourgeoisie therefore, is defined in the first instance by the distinction between productive and unproductive labor and secondarily by relations of ideological and political domination and subordination. The result is that a substantial proportion of productive laborers are included in the new petty bourgeoisie along with unproductive laborers.

The division between the new petty bourgeoisie and the capitalist class in Poulantzas's writings is analyzed primarily in terms of the relations of ownership and possession discussed above. Like the working class, the new petty bourgeoisie is excluded from legal ownership, economic ownership, and possession of the means of production. They are also subordinated to capital within political and ideological relations. Overall, then, the new petty bourgeoisie can be considered a class that is itself dominated by capital economically, politically, and ideologically, and yet occupies a position within class relations of economic and/or political and/or ideological domination of the working class. Taking all of these criteria together, we have the rather complex typology presented in table 5 .

Two things in particular are worth noting in this typology. First, the working class is defined very narrowly by these criteria. If a position deviates in any way from the pattern of the pure proletariat, that position is excluded from the working class altogether. The result is that the working class becomes a small minority of the American population. The size of the working class, using Poulantzas's criteria, is probably no more than 20 percent of the economically active popula- 
TABLE 5

General Criteria for Class Position in Poulantzas's Analy sis

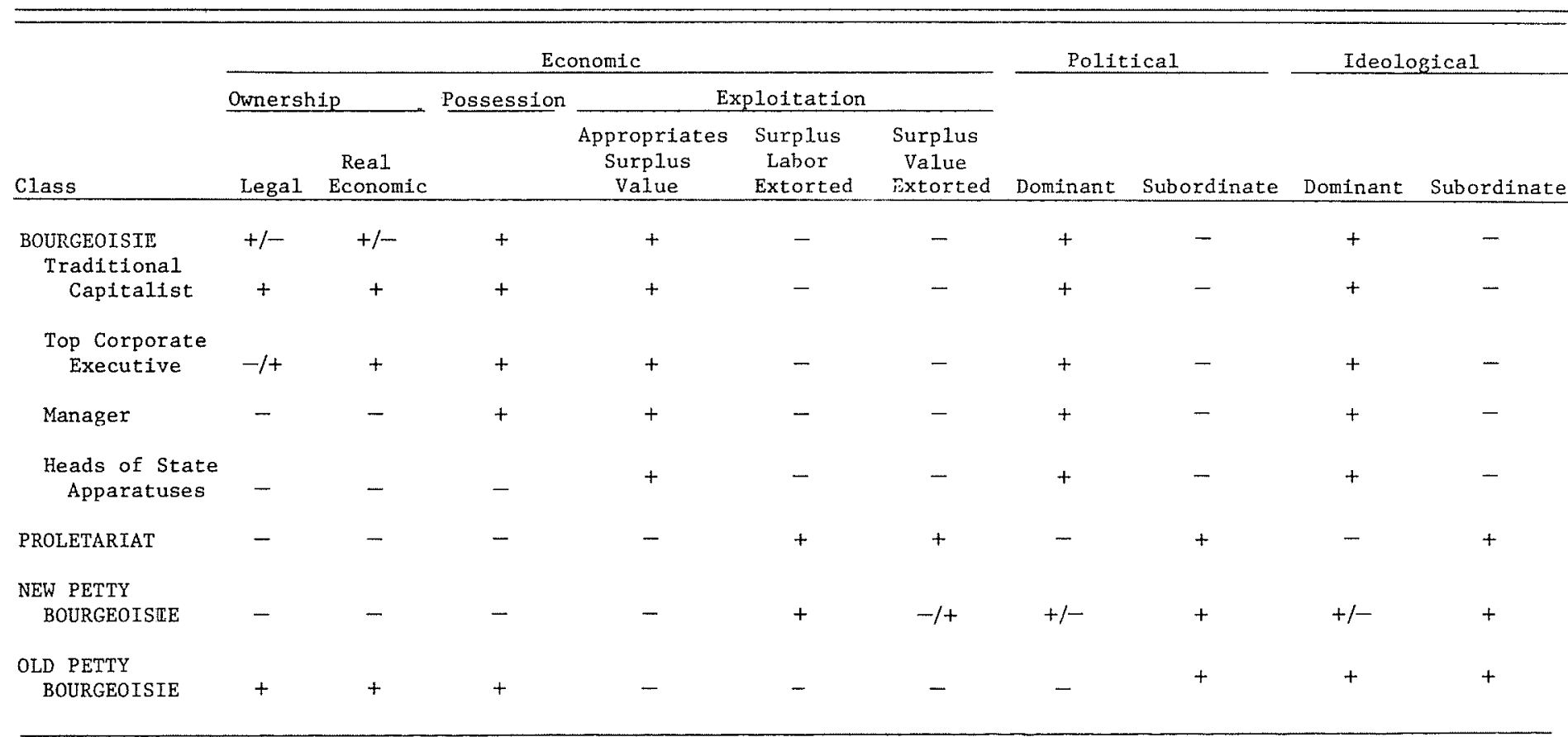

NOTE: $+=$ yes; $-=$ no; $+/-=$ usually yes; $-/ t=$ usually no.

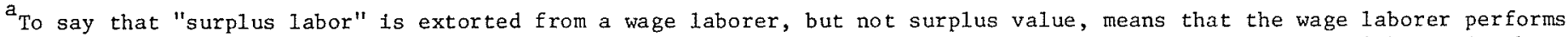

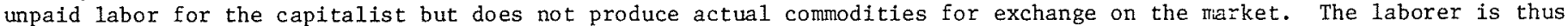
not formally productuve, but is still exploited. 
tion in the United States. ${ }^{30}$ Second, the capitalist class is defined extremely broadly by Poulantzas. A mere manager who does not participate in economic ownership relations, has no legal ownership of the means of production, but does participate in decisions about how the production process should be run, is placed in the bourgeoisie proper. "In all cases, therefore," Poulantzas writes, "the managers are an integral section of the bourgeois class." 31

\section{Critique}

The basic criticism of these conceptions of the class structure is the importance they place on the distinction between productive and unproductive labor. If one is to place two positions within the social division of labor into different classes on the basis of economic criteria, then these positions must have fundamentally different class interests at the economic level. Is this plausible for the distinction between productive and unproductive labor in general? Both productive and unproductive labor are exploited, in the sense that unpaid labor time is appropriated from them. The only difference is that in the case of productive labor, unpaid labor time is directly appropriated as surplus value, whereas in the case of unproductive labor, unpaid labor merely reduces the costs to the capitalist of appropriating part of the surplus value produced elsewhere. In both cases the capitalist will try to keep the wage bill as low as possible. In both cases workers will be dispossessed of control over the labor process. In both cases capitalists will try to increase productivity, to get workers to work harder. And in both cases, socialism is a prerequisite for ending exploitation. It is hard to see where a fundamental divergence of economic interests emerges from the positions of unproductive and productive labor within capitalist relations of production. (This is not, of course, to deny that conflicts of immediate interest may arise between productive and unproductive labor, just as they do continually between different subcategories of the industrial proletariat itself.)

Even if it were the case that unproductive laborers had fundamentally different interests from the working class, it would still be very difficult to designate them petty bourgeois, "new" or otherwise. The same argument applies as in the critique of the idea that credentials constitute a form of petty bourgeois property: the objective locations of unproductive wage labor and the self-employed, traditional petty

30. See Wright, Class, Crisis and the State, p. 57, for a discussion of this estimate.

31. Poulantzas, Contemporary Capitalism, p. 180. 
bourgeoisie are so qualitatively different that it is hard to see how they can be considered members of a common class. Traditional petty bourgeois are not even directly engaged in the capitalist mode of production, but in simple commodity production. While they are generally subordinated to capital through market relations, they are not in a direct production relation with capital. Unproductive wage labor, however, is an essential element in the capitalist mode of production itself. Unproductive workers are directly dominated by capital in production.

Poulantzas's response to this critique is that while it is true that traditional petty bourgeois producers occupy very different economic positions from the new petty bourgeoisie, nevertheless these different economic locations produce the same effects at the level of ideology. This ideological unity of the petty bourgeoisie is sufficiently strong to warrant designating both old and new petty bourgeoisie as parts of a single class. Poulantzas cites the individualism and careerism of both old and new petty bourgeoisie as examples of this unified ideology.

This defense seems to me inadequate, for two reasons. First, the argument that a common ideology, no matter how strong, can constitute the basis of a common class location is totally inconsistent with the claim that the class structure is fundamentally determined by the social relations of production. While ideological factors may have an important role in reinforcing or weakening class antagonisms, and they certainly play a critical role in the process of class formation, they cannot negate fundamental differences at the level of production relations. Second, Poulantzas's claim that the old and new petty bourgeoisie have essentially similar ideologies is itself open to serious question. Both may be individualistic, but the individualism of the traditional petty bourgeoisie ("Be your own boss," "the self-made man") is radically different from the individualism of the "new" petty bourgeoisie ("the aggressive organization man"). In the former case, individualism is an ideology of autonomy and independence; in the latter it is an ideology of competitive careerism and ambition within bureaucratic relations of dependence and domination. These differences reflect in part the basic differences in their location within production relations. Furthermore, in terms of explicitly political ideology, the two categories also differ markedly: the old petty bourgeoisie, at least in the United States, tends to be ultraconservative and antistate, while the technical, professional, and managerial employees of the new petty bourgeoisie are often more liberal, more in favor of the welfare state, and so on.

\section{Underexploited Wage Earners and the New Petty Bourgeoisie}

This position has been most forcefully argued in a very interesting 
book on the French class structure by Christian Baudelot, Roger Establet, and Jacques Malemort. ${ }^{32}$ They reject the notion that unproductive wage earners should be viewed as benefiting in any way from exploitation. Even though they do not produce surplus value, their labor power is paid at its value, and they do perform surplus labor (labor time in excess of the value of their labor power) for the capitalist. Some wage earners, however, do receive a wage that is actually in excess of the value of their labor power. In the extreme case, as in top managers of corporations, such wage earners may cease to be exploited altogether, performing no unpaid labor for capital. In any event, such underexploited wage earners do have a real stake in raising the rate of exploitation of the working class, and thus they occupy a class position antagonistic to the working class.

Baudelot et al. define the petty bourgeoisie as "all those who, by virtue of the place which they occupy in the relations of production, receive from the bourgeoisie a fraction of the social surplus value. That is to say: the petty bourgeoisie are those who are not capitalists and who receive as income-through whatever form (salary, commercial profit, commissions) a sum of money greater than the value of their labor power."33 By this definition, it should be noted, peasants and artisans are not petty bourgeois. Since all of their income comes directly from their own labor (self-earned income) and not from the redistribution of surplus value, they occupy a distinct class position not dependent on the exploitation of the working class by the bourgeoisie. The petty bourgeoisie consists of all those positions that receive through various specific mechanisms part of the surplus value appropriated from the working class, without themselves belonging to the capitalist class.

On the basis of this definition, Baudelot et al. attempt to make rough calculations of that proportion of the income of various categories of skilled white-collar occupations that is above the value of the labor power of the average incumbent of the occupation. The method by which they make these calculations is designed to maximize the estimated value of labor power of the various categories in order to make it as difficult as possible to demonstrate an income in excess of this value. ${ }^{34}$ Yet their final results are quite striking: 55 percent

32. Christian Baudelot, Roger Establet, and Jacques Malemort, La Petite Bourgeoisie en France (Paris: Maspero, 1974).

33. Tbid., p. 224.

34. The value of labor power is generally defined by Marxists as the total, socially necessary costs for producing and reproducing a given type of labor power. Clearly, these costs vary with the extent of the training of the labor power (since skills themselves cost something 
of the income of upper managers, 48 percent of the income of engineers, 41 percent of the income of university professors, and 27 percent of the income of technicians is above the value of their labor power. ${ }^{35}$ Since these elevated incomes depend upon the exploitation of the working class, these positions become directly tied to the interests of the bourgeoisie and thus fall outside the working class. Still, they are not part of the bourgeoisie, since they are themselves wage laborers, still partially exploited, and still dominated within production by the capitalist class. They thus fall into an intermediary class position, the petty bourgeoisie.

\section{Critique}

The strategy adopted in this analysis is very ingenious. Yet it is still questionable whether it establishes the validity of defining these positions as all part of a single class, the petty bourgeoisie, simply by virtue of their elevated incomes. To be sure, Baudelot et al. emphasize that it is "because of their location within production relations" that they receive such elevated incomes, but they fail anywhere systematically to theorize exactly what it is about their location within the production relations that confers on them such income privileges. ${ }^{36}$

In fact, the various components of the petty bourgeoisie enumerated by these authors occupy very different positions within the social relations of production. Some of them are self-employed merchants and professionals, selling services and commodities directly on the market. Others are managers, directly subordinated to capital within production while at the same time dominating labor, thus occupying positions within the heart of the capitalist relations of production. And others are wage earners excluded from any role in

to produce and maintain) as well as with various other special characteristics. Baudelot et al. attempt to measure a very broad range of factors that could reasonably be thought of as components of the value of labor power of skilled wage earners. They include such things as the reproduction costs needed to rejuvenate mental activities, the costs of books and other materials to keep abreast of particular fields, the direct and indirect costs of training, and even the costs of training the next generation in the same skills. Even when all of these costs are montized, Baudelot et al, are still able to demonstrate that the average wage of many professional, technical, and managerial occupations is considerably above the value of their labor power. For an extended discussion of the value of labor power, see Erik Olin Wright, "Debates on the Labor Theory of Value," New Left Review, no. 16 (July-August 1979).

35. Baudelot et al., La Petite Bourgeoisie en France, p. 234.

36. For an analysis of the relationship between the income determination process and locations within the social relations of production, see Erik Olir: Wright and Luca Perrone, "Marxist Class Categories and Income Inequality," American So cological Review 42 (1976): 32-55; Erik Olin Wright, "Race, Class and Income Inequality," A', $\epsilon^{\prime}$ can Journal of Sociology 83 (1978): 1368-97; and idem, Class Structure and Income Determin. ion, chaps. 3, 4. 
directly dominating labor at all. While it may be that for various reasons all of these positions receive "income privileges," this is, as in the other versions of new petty bourgeoisie theory, an inadequate basis for arguing that they all occupy a common position within the social relations of production, and thus a common class location.

The overriding problem with all of these versions of the new petty bourgeoisie conception of the class structure is the claim that certain categories of wage laborers occupy the same class location as various categories of self-employed small businessmen and shopkeepers. Each of the three versions we have examined provides different criteria for excluding certain positions from the working class (possession of credentials or skills, peformance of unproductive labor, income in excess of the value of labor power), but they all argue that these positions, which are outside the working class, form part of the petty bourgeoisie. For reasons already outlined, such claims violate the basic logic of identifying class structure in terms of common locations within the social relations of production.

\section{CONCEPTIONS OF THE CLASS STRUCTURE IN TERMS OF THE EMERGENCE OF A "NEW CLASS"}

One solution to the problem of new petty bourgeoisie conceptions of the class structure is to argue that those categories of wage earners that fall outside the working class constitute a new class in their own right, distinct from the petty bourgeoisie as well as from the working class and the capitalist class. ${ }^{37}$ This position has been most forcefully argued by Barbara and John Ehrenreich. ${ }^{38}$

The Ehrenreichs argue that in the course of capitalist development a distinctive new class has emerged; they call it the "ProfessionalManagerial Class" (PMC for short). The PMC is defined as: "consisting of those salaried mental workers who do not own the means of pro-

37. This view of the class structure must not be confused with various non-Marxist claims that the capitalist class has been superseded by a new ruling class of managers in advanced industrial society. This position has been extensively argued by James Burnham in The Managerial Revolution (New York: Random House, 1938), by Dahrendorf in Class and Conflict in Industrial Society; and for Eastern Europe by Milovan Djilas in The New Class (New York: Praeger, 1957). The thesis being discussed in this section concerns the emergence of a new subordinate class, not a new ruling class.

38. The Ehrenreichs' original essays appeared in 1977 in Radical America, vol. 11, nos. 2, 3. These essays have been reprinted along with a series of critical commentaries on their work and a rejoinder in Between Capital and Labor, ed. Pat Walker (Boston: South End Press, 1979). 
duction and whose major functions in the social division of labor may be described broadly as the reproduction of capitalist culture and capitalist class relations." ${ }^{39}$ As a class, the PMC has developed its own specialized organizations (professional associations), its own specific ideology (technocratic liberalism), and its own recruitment and training structures (universities, especially elite institutions). Its interests are clearly different from those of both the capitalist class and the working class. While the PMC are dependent upon the bourgeoisie for their positions, the bourgeoisie is seen as thwarting their vision of a technocratically organized, postindustrial society. And while they share with workers an antipathy to bourgeois domination, they are set at odds to the working class because of their objective role in reproducing the subordination and exploitation of workers. The PMC is thus caught between capital and labor in a complex web of conflicting and complementary class interests.

\section{Critique}

In many ways, the Ehrenreichs' analysis is a considerable improvement over the various atttempts at seeing professional, technical, and managerial employees as part of the petty bourgeoisie. The contradictory character of their class interests is much better treated by considering them a distinct class than by merging them with the traditional petty bourgeoisie. Nevertheless, this perspective still suffers from several shortcomings. Two of these are especially important: problems with the functional character of the definition of classes; and the hypothesis of the class unity of positions within the PMC.

At first glance the functional discussion of classes seems like a useful way of grappling with the relationship of managers, professionals, and other such positions to the working class. Many of these positions are not immediately engaged in production, and much of their activity can be seen as having the effect of reproducing class relations (that is, "serving" the function of reproduction). The problem, however, is that functional effects are rarely completely coincident with structural positions, making it difficult to base a typology of positions on a logic of functional relations.

This general problem is particularly striking in the distinction between the functions of "production" and "reproduction." As Marx's classic analysis of commodity fetishism has demonstrated, a great deal

39. Barbara Ehrenreich and John Ehrenreich, "The Professional-Managerial Class," Radical America 11, no. 2 (1977): 13. 
of the burden of reproducing class relations takes place directly within the labor process itself. In effect, industrial workers "perform" the function of reproduction simply by engaging in the capitalist production process.

The Ehrenreichs, of course, are not concerned so much with reproduction in general, as they are with the specialized performance of reproductive activities. While factory workers may contribute to the reproduction of class relations, their work cannot be considered specialized in the function of reproduction. Limiting ourselves to the cases where such specialized performance of the reproductive function occurs, however, does not entirely solve the difficulties. Many professionals in such positions-engineers, technicians, even managerssimultaneously are engaged in directly productive functions, activities directly contributing to production. When an engineer designs a bridge, for example, he or she is participating in one stage of the actual production process. While it may be true that the status of the engineer as an expert has the effect of contributing to the reproduction of class relations, there is no a priori basis for saying that this aspect of the engineer's role is the predominant one. Except in the few cases where only a single function is performed, it is difficult to see how an adequate criterion for assigning the proper weights to different functions can be obtained.

One final problem with functional definitions is worth noting. It can be argued that certain institutions in capitalist societies serve almost exclusively the function of reproducing class relations. The propaganda arms of governments are perhaps the simplest examples, but a case can be made for the ideological and repressive apparatus of the state in general. If such institutions globally serve the function of reproducing class relations, then the activity of all employees within the apparatus must be seen as serving this function. A typist or janitor on a military base, therefore, would be contributing to the function of reproducing class relations and thus fall into the PMC.

If a structural, rather than functional, definition of class relations is adopted, this problem immediately disappears. The question then becomes the relations of domination and control within a particular institution, rather than simply the function of the institution as a whole. Since typists and janitors are totally excluded from any participation in such control, they would be considered part of the working class.

The hypothesized class unity of the PMC is as serious a difficulty as the functional logic of the definition of the class itself. As we have argued in our criticisms of the new petty bourgeoisie theories, for a 
set of social positions to be considered a class they must share fundamental class interests, and furthermore, those interests must be differentiated from those of other classes. Fundamental interests, it will be recalled, are interests defined in terms of modes of production. Does the PMC as analyzed by the Ehrenreichs have such unified class interests?

By their own account, such a unity of interests is very problematic. The PMC includes top executives, teachers, engineers, nurses. While it may well be that both nurses and top corporate executives are differentiated from the working class at the ideological level in terms of social status, they hardly share fundamental interests in terms of the social organization of production. Indeed, the Ehrenreichs go so far as to suggest that in a certain sense nurses are "closer" to the working class than they are to top managers. This would suggest that they have more in common with workers-that is, that their class interests overlap more with workers-than they have with certain categories within the PMC itself. If this is the case, then it is hard to see how the PMC can be viewed as a class in its own right, with genuine class interests. If a class means anything at all, it implies that members of that class have more class interests in common with each other than they do with members of the other classes.

\section{CONTRADICTORY LOCATIONS WITHIN CLASS RELATIONS: FUNCTIONAL VERSIONS}

All of the treatments of class structure that we have examined so far-the simple polarization views of class, the new petty bourgeoisie views and the new class views-share one basic assumption: all positions within the class structure must fall into only one class. While they have different solutions to how to set up a typology for that structure, they all agree that there is a simple mapping of positions into classes. None of these interpretations of the class structure countenance locations within class relations that are not part of classes. ${ }^{40}$

40. A number of the writers we have discussed do recognize that the classes into which they place various ambiguous social positions are not "classes" in precisely the same sense that the working class and the bourgeoisie are classes. Poulantzas, for example, emphasizes that the new petty bourgeoisie is not capable of autonomous positions within the class struggle but is always subordinated in one manner or another to the basic class forces of capitalist society. Poulantzas even goes so far as to argue that the "bottom layers" of the new petty bourgeoisie are more likely to form alliances with the working class than the top layers. This comes close to treating the new petty bourgeoisie as a contradictory location within class relations rather than a class per se. But Poulantzas does not take the next step and continues to regard the new petty bourgeoisie as part of the same class as the old petty bourgeoisie. In 
The concept of contradictory locations within class relations is intended to provide an alternative general solution to these problems of analyzing class structure. Instead of insisting that all ambiguous categories within the class structure belong into one class or another, certain positions are recognized as being objectively situated in more than one class (or, equivalently, objectively torn between classes). Such contradictory locations must be studied in their own right rather than obliterated by an attempt to pigeonhole all social positions into distinct classes.

It is, of course, insufficient simply to argue that certain positions are objectively torn between classes. It is also necessary to provide a systematic analysis of class relations that rigorously defines the nature of the objectively contradictory locations. Two general strategies for analyzing such contradictory locations have emerged in the recent literature. The first has already been discussed: the relations of domination and subordination characterizing the social relations of production are broken down into several interdependent relations, and contradictory locations are defined as noncorresponding combinations of these relations.

The second version, for convenience, will be referred to as the functional account of contradictory locations, although as we shall see it involves more than a simple functional analysis of class relations. ${ }^{41}$ This perspective has been most systematically developed in the work of G. Carchedi. ${ }^{42}$ Carchedi's original argument has been somewhat simplified and extended in a number of different ways in a recent book by Rosemary Crompton and Jon Gubbay. ${ }^{43}$ I will concentrate on Carchedi's original formulation in this discussion since it is the most elaborate exposition of the argument.

Carchedi defines class positions in terms of three general dimensions which he refers to as the ownership, expropriation, and functional

a similar fashion, the Ehrenreichs, as has already been mentioned, see the PMC as internally divided in ways that place certain segments closer to the working class than others.

41. The term contradictory locations does not appear in the work of theorists who defend the functional version. G. Carchedi prefers to use ine term new middle class and Rosemary Crompton and Jon Gubbay the expression structurally ambiguous class positions. In both cases, however, the essential notion is very close to that of contradictory locations, and thus I will use that expression to cover their perspective as well as my own.

42. G. Carchedi, "On the Economic Identification of the New Middle Class," Economy and Society, vol. 4, no. 1 (1975); and idem, "Reproduction of Social Classes at the Level of Production Relations," Economy and Society, vol. 4, no. 4 (1975). These essays have been reprinted in idem, On the Economic Identification of Social Classes (London: Routledge \& Kegan Paul, 1977).

43. Rosemary Crompton and John Gubbay, Economy and Class Structure (New York: St. Martin's Press, 1978). 
elements. ${ }^{44}$ The first of these is similar, but not identical, to my usage of the term economic ownership. In my analysis, economic ownership refers to control over investments and the accumulation process and is to be distinguished from possession, which refers to control over the physical means of production. Carchedi also contrasts economic ownership with possession, but he uses both terms in slightly different ways. Ownership is defined as "the power to dispose of the means of production and the labor power," while possession is defined as "the ability to set in motion and to govern the means of production." 45 Possession, Carchedi insists, is a characteristic of the working class, not of the capitalist class, since it is in fact the workers who concretely "set in motion" the means of production. In any event, economic ownership still refers to real control, as opposed to legal title, and for present purposes can be considered similar to the concept developed in my own analysis.

The expropriation element refers to the extent to which a position involves the performance of unpaid labor, on the one hand, or the expropriation of other people's unpaid labor time, on the other. When unpaid labor is expropriated in the form of surplus value, that is, when the labor is productive, Carchedi says that it is "exploited." When unpaid labor time is expropriated directly as labor, he calls it "economic oppression."

The heart of Carchedi's analysis revolves around the functional element, that is, the function performed by specific positions within the social relations of production. Of particular importance is the social content (as opposed to the technical content) of functions within the production process. In the monopoly phase of capitalism these functions can be divided into the "global function of capital" and the "function of the collective worker." These concepts grow out of an analysis of three phases of capitalist development. The first phase is what Carchedi calls the "private capitalist mode of production characterized by formal subordination of labor to capital." This corresponds to the earliest period of capitalist development in which workers were gathered together under the formal control of the

44. In Carchedi's first essay ("The New Middle Class") he begins the analysis with a fourfold set of dichotomies: owner and nonowner; laborer and nonlaborer; producer and nonproducer; and exploiter and nonexploiter. The second and third of these are basically combined in the "functional element" discussed above. The function of the collective worker can be described as the function of producer (of surplus value) and laborer (participant in the labor process), while the function of capital can be described as nonproducer (no unpaid labor time) and nonlaborer (participates in the control and surveillance of the labor process, but not in the labor process itself).

45. Carchedi, "Reproduction of Social Classes," pp. 362, 363. 
individual capitalist in a single workshop, but each individual laborer still controlled the entire labor process (that is, there was negligible division of labor within production).

In the second phase, called the "private capitalist mode of production characterized by real subordination of labor to capital," the modern factory is born, with a detailed division of labor and the general destruction of workers' control of the labor process. In this phase, production is carried out by the "collective worker" rather than simply by an aggregation of individual workers, that is, the production process requires the integration and coordination of many fragmented labor processes. In the final phase, the monopoly capitalist mode of production, production is no longer controlled by capitalists as individuals, but by what Carchedi terms the "global capitalist," capitalists organized as a collective, differentiated, managerial structure.

To understand the class position of workers and capitalists in monopoly capitalism, therefore, we must understand exactly what defines the function of the global capitalist and the function of the collective worker within the social relations of production. Carchedi concludes that the essential function of the global capitalist is "the control and surveillance" of the labor process, while the essential function of the collective worker is "to take part in the complex, scientifically organized labor process (i.e., in the production of use-values, either material or not) as a part of the collective laborer, as agents through which capital in the productive sphere produces and appropriates directly surplus value (economic exploitation) or through which capital in the unproductive sphere participates in the sharing of surplus value produced in the productive sphere of the economy (economic exploitation)." 46 The key elements of this rather complex definition are: that the function of the collective worker involves participation in the production of use-values (that is, the labor process); that this labor process is complex and scientifically organized (that is, there is a detailed division of labor) so that no individual worker produces the entire commodity; and that unpaid labor is expropriated from the worker either as surplus labor or as surplus value.

One important aspect of the function of the collective worker is what Carchedi calls the "work of coordination and unity in the capitalist production process." This must not be confused with the "work of control and surveillance." Control and surveillance refers to the role of the capitalist in guaranteeing that surplus value is generated in the production process; coordination and unity, however, are

46. Carchedi, "The New Middle Class," p. 29. 
part of the labor process itself, one aspect of the collective activity necessary to produce use-values.

We can now define contradictory locations in Carchedi's terms. Contradictory class locations (or what Carchedi refers to as the new middle class) are defined by positions that are excluded from economic ownership of the means of production but that participate in both the global function of capital and the function of the collective worker in a variable balance. They are thus both exploiting and exploited. This definition is illustrated in table 6 . In Carchedi's words:

Thus, in terms of production relations, we can define the capitalist as the agent of production who occupies a position resting on ownership of the means of production, on the expropriation of surplus value and on the performance of the function of capital. Concisely, we can identify the capitalist as the owner/nonlaborer/exploiter. Conversely, we can identify the working class as the non-owner/ laborer/exploited. . . . The middle classes, however, are only identifiable in terms of contradiction. For example, there are positions, and thus agents, identifiable in terms of nonownership of the means of production and the performance of the global function of capital. This is one section of the new middle class. ${ }^{47}$

The top layers of this "new middle class" are heavily weighted on the global function of capital; the bottom layers on the function of the collective worker. In all cases, the distinctive characteristic of the new middle class is their performance of both functions, and thus their contradictory location within class relations.

Carchedi uses this schema to pursue an interesting analysis of the proletarianization of contradictory locations. Just as capital constantly tries to increase productivity within the working class proper, so it tries to shift the balance between the global function of capital and the function of collective worker embodied in contradictory class locations. This is accomplished primarily through technical changes that reduce the necessary qualifications of such positions ("dequalification" of labor power) and thus reduce their responsibility within the social division of labor:

One major source of change is the introduction of new techniques. This introduction will bring about a change in the technical content of functions and perhaps in their social content as well. This can be seen most clearly in the case of the proletarianization of a part of the new middle class, i.e., of those agents of production who, in terms of the function performed, perform both the global function of capital and the function of the collective worker. The devaluation of these agents' labor power, through the reduction of their labor from a skilled to an average level, usually takes place through the fragmentation of tasks, etc. (a change in the technical nature of the function performed). This reduces re-

47. Carchedi, "Reproduction of Social Classes," p. 369. 
TABLE 6

Class Locations in Carchedi's Analysis

\begin{tabular}{|c|c|c|c|c|c|c|c|c|}
\hline \multirow[b]{2}{*}{$\begin{array}{l}\text { Form of } \\
\text { Capytalist } \\
\text { Production }\end{array}$} & \multirow[b]{2}{*}{$\begin{array}{c}\text { Class } \\
\text { Positions }\end{array}$} & \multirow{2}{*}{$\begin{array}{l}\text { Ownership Element } \\
\text { Real Economic } \\
\text { Ownership of the } \\
\text { Means of Production }\end{array}$} & \multicolumn{2}{|c|}{ Expropriation Element } & \multicolumn{3}{|c|}{ Eunctional Element } & \multirow[b]{2}{*}{$\begin{array}{l}\text { Performs th } \\
\text { function of } \\
\text { collective } \\
\text { worker }\end{array}$} \\
\hline & & & $\begin{array}{l}\text { Expropriates } \\
\text { Surplus } \\
\text { Labor }\end{array}$ & $\begin{array}{l}\text { Surplus } \\
\text { Labor } \\
\text { Expropriated }\end{array}$ & $\begin{array}{l}\text { Performs } \\
\text { the functips } \\
\text { of Capital }\end{array}$ & $\begin{array}{l}\text { Performs } \\
\text { the function } \\
\text { of Labor }\end{array}$ & $\begin{array}{l}\text { the } \frac{\text { Global }}{\text { function } g^{f}} \\
\text { capital }\end{array}$ & \\
\hline Early & Capitalist class & + & + & - & + & - & & \\
\hline private & Old middle class & + & + & + & + & + & & \\
\hline capitalism & Working class & - & - & + & - & + & & \\
\hline \multirow{3}{*}{$\begin{array}{l}\text { Developed } \\
\text { private } \\
\text { capitalism }\end{array}$} & Capitalist class & + & + & - & + & & & - \\
\hline & old middle class & + & + & + & + & & & + \\
\hline & Working class & - & - & + & - & & & + \\
\hline \multirow[t]{8}{*}{$\begin{array}{l}\text { Monopoly } \\
\text { capitalism }\end{array}$} & $\begin{array}{l}\text { Monopoly } \\
\text { Capitalist Class }\end{array}$ & + & + & - & & & + & - \\
\hline & Top Executives & + & + & - & & & + & - \\
\hline & Top Managers & - & + & - & & & + & - \\
\hline & New middle class & - & + & + & & & + & + \\
\hline & Top Levels & - & high ${ }^{\mathrm{f}}$ & Low & & & High & Low \\
\hline & Middle Levels & - & Medium & Medium & & & Medium & Medium \\
\hline & Bottom Levels & - & Low & Medium & & & Low & High \\
\hline & Working class & - & - & + & & & - & + \\
\hline
\end{tabular}

${ }^{\text {a }}$ prtvate capitalism refers to situations in which there is a simple, one-to-one relationship between legal ownership and real economic ownership (i.e., the family firm). In Monopoly Capitalism, real economic ownership is organized collectively, not individually. It should be noted that while contemporary capitalism is dominated by monopoly capitalism, the earlier forms continue to exist, and thus they continue to determine class locations.

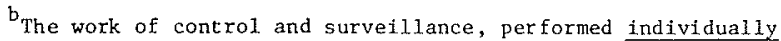

$\mathrm{c}_{\text {The work }}$ of direct production, performed individually

The work of control and surveillance, performed through a complex division of labor

The work of direct production, performed through a complex division of labor

$f_{\text {High, }}$ medium, and low refer to the relative balance of opposing elements 
sponsibility and originates a tendency to lose control and surveillance over other agents; a reduction (or loss) in the global function of capital (a change in the social nature of the function performed). ${ }^{48}$

While Carchedi has no more than anecdotal evidence that such dequalification of "middle-class" positions is a general tendency in advanced capitalism, he argues that, overall, many contradictory class positions are becoming closer to the working class and that this has considerable implications for working-class political and economic struggles.

Critique

Carchedi's analysis is the closest to my own of any of the perspectives I have discussed. He explicitly analyzes class structure in terms of contradictory combinations of various dimensions of class relations, and he understands that certain positions within the class structure are torn between classes rather than falling neatly within any given class.

There are, however, certain important differences in the two strategies of analysis. The most immediately obvious of these is that Carchedi's analysis revolves around a single contradictory location, whereas in my analysis there are three quite distinct contradictory locations: managers and supervisors occupy the contradictory location between the working class and the bourgeoisie; semiautonomous employees, the contradictory location between the working class and the petty bourgeoisie; and small employers, the contradictory location between the petty bourgeoisie and the bourgeoisie. Carchedi only considers the first of these. Semiautonomous employees are merged with the working class, and small employers (which he calls the "old middle class") are merged with the contradictory location between the capitalist class and the working class.

Why are these two contradictory locations absent from Carchedi's analysis? The answer can be found if we look closely at the elements in the definition of class relations adopted in the two versions of the analysis of contradictory class locations. The first element, economic ownership, is very similar in both analyses. While I give this dimension of class relations a slightly narrower connotation than does Carchedi, by defining it in terms of the control over the accumulation process as a whole (surplus value, investments), the basic content of the concept is similar in both analyses. Carchedi's second element, expropriation, does not appear explicitly in my schema at all. In effect, all of

48. Ibid., p. 376 . 
the dimensions of production relations are relations of exploitation, since the appropriation of surplus labor is a consequence of domination (control) over investments, physical capital, and labor. Relations of exploitation were not explicitly added to the schema in table 1 because they were seen as redundant. Furthermore, this omission is not the source of the difference between the two analyses because in Carchedi's analysis the expropriation element perfectly coincides with the functional element and is thus redundant as a formal criterion.

The critical difference in our analyses of contradictory locations can be found in Carchedi's third element of class relations, the "functional element." There is no serious problem with the global function of capital-the work of control and surveillance of the labor process. In general terms at least, this is virtually identical to the third dimension of production relations in my own analysis (some secondary differences will be discussed later). But where is the second dimension of production relations that I discuss, control over physical capital (the physical means of production)? At first glance it appears absent from Carchedi's typology, but in fact, it constitutes the critical content of the "function of the collective worker" in his analysis.

This, then, is the central difference between our formal schemas: Carchedi considers possession of the physical means of production one aspect of the function of the collective worker; he terms it the work of unity and coordination within the labor process. I consider full possession of the means of production a characteristic of the capitalist position within the social relations of production.

The difference in these two positions hinges, I think, on the distinction between the social and technical aspects of production relations. This is very similar to the problems we encountered earlier in the discussion of the work of Cutler, Hindess, Hirst, and Hussain. It is certainly the case that no complex production process can take place without a certain amount of planning, coordination, allocation of resources to different activities, and selection of appropriate technologies. There is, therefore, a sense in which all of these activities of control over the physical means of production are "technically" necessary for production. But it is also the case that the decisionmaking structure developed within capitalist enterprises in order to accomplish these technical operations is not itself technically determined. The control of the decisions concerning technically necessary activities is itself a social relation, indeed, a dimension of class relations. Capitalists "possess" the means of production (as well as "own" them) in the precise sense that they control the decision-making activities 
around the allocation and use of the physical means of production. This does not imply that they actually make all these decisions. On the contrary, the very existence of contradictory class locations is premised on the delegation by capitalists of certain of their powers to managerial agents. But they do control the process itself.

In Carchedi's analysis, all activities that are technically necessary for production are part of the function of the collective worker. Since planning and coordination are technically necessary, planners and coordinators (managers) perform the function of the collective worker. It is only in their capacity as controllers of labor that they perform the function of capital, not in their capacity as decision makers over the running of the actual production process.

This way of treating possession creates some curious anomalies. In Carchedi's analysis many foremen on an assembly line would primarily perform the function of capital. While some foremen are involved in coordinating production, in many situations the central responsibility of foremen is surveillance and control. Many middle and upper managers, however, spend virtually no time at all in control and surveillance activities. Rather, their preoccupation is with long-run planning of production, market evaluations, general decision making about production processes. In effect, therefore, in terms of Carchedi's functional element at least, foremen could well be much closer to the capitalist class than top managers, while some top managers might even be almost fully workers (in functional terms).

This anomaly disappears as soon as possession of the means of production is viewed as a power relation, not a technical relation. The participation of top managers in major decisions concerning the coordination and planning of production then becomes an aspect of their closeness to capital. Again, this is not to deny that such planning activity is technically necessary for production in advanced capitalism. It undoubtedly is, and this demonstrates that many top managerseven some proper monopoly capitalists-perform certain technically useful functions. The point is that it is not the technical necessity of the activity for production but the relations of domination and subordination within which that activity takes place that is the decisive issue.

Once we shift to an emphasis on the relations of domination and subordination, it then becomes possible to specify different positions within each of the dimensions of production relations used in the analysis. In particular, in the present context, one can talk about different levels of possession of the means of production. This is what makes it possible to define the semiautonomous-employee 
category: these are wage laborers who do not participate in the control of other workers but do have control over their own immediate labor process. Given Carchedi's emphasis on the function of the collective worker and his understanding of possession, it is impossible for him to define this category, the contradictory location between the working class and the petty bourgeoisie.

Viewing possession as a power relation also makes it easier to understand the class location of small employers and to differentiate it from that of both managers and the traditional petty bourgeoisie. In Carchedi's analysis, small employers are seen as performing the functions of both capital and the collective worker. They differ from managers in the monopoly corporation by having economic ownership of the means of production, and by performing the function of capital as individuals rather than collectively. But they are fundamentally like managers in performing both functions, and thus in Carchedi's analysis both managers and small employers occupy a contradictory class location between the working class and the bourgeoisie; this is also why he can refer to them as old and new parts of the "middle class."

In my analysis, small employers occupy a contradictory location between the petty bourgeoisie and the capitalist class, that is, a contradictory location between modes of production, rather than within the capitalist mode of production. This characterization is possible because possession is not seen as a function of the collective worker, but as a relation of domination within production. Both the petty bourgeoisie and small employers possess their means of production, and both of them also have economic ownership of the means of production. Where they differ is in their control over labor: small employers do perform the function of capital (in Carchedi's terms); petty bourgeois producers do not. In these terms, therefore, small employers occupy a contradictory position between the petty bourgeoisie and the capitalist class.

The difference between the two conceptions is well illustrated in the analysis of the income of small employers. In my analysis, that income should be understood as partially self-earned (the petty bourgeois component) and partially the result of exploitation (the capitalist component). In Carchedi's view, small employers are seen as both exploited (when they perform the function of the collective worker) and exploiters (when they perform the function of capital).

It is probably premature to attempt a final balance sheet between these two alternative strategies of defining contradictory class locations. Both approaches contain significant areas of ambiguity, and both are still very much in the process of refinement. As they currently stand, 
the advantage with Carchedi's analysis is his attempt to incorporate directly into the dimensions of class relations the distinctive transformations within capitalist production. Nowhere in my schema, for example, does the distinction between the individual and the collective performance of activities of control and surveillance appear. The advantage of my strategy is that it allows for a more differentiated picture of various kinds of contradictory locations within class relations. The structural analysis facilitates the designation of different levels of control within specific relations, thus making it possible to indicate where within a contradictory location a specific position is situated. And the particular way in which these three dimensions of relations have been conceptualized makes it possible to distinguish certain contradictory locations that are merged in Carchedi's analysis.

\section{CONCLUSION}

Marxism is not fundamentally a theory of class structure. It is above all a theory of class struggle and social change. The analysis of class structure is intended not as the end point of an investigation, but as the starting point. The premise is that the structure of class relations establishes the basic context within which social struggle and change will take place. The purpose of studying class structure is to be able to understand the constraints on and possibilities of transformation. Ultimately, for Marxists, this means understanding the conditions for the formation of a working class capable of generating revolutionary socialist change.

The various contending images of class structure that we have examined can thus be interpreted as contending accounts of the constraints on the process of class formation. In effect, the different definitions of the working class can be seen as alternative propositions about the structural basis for the formation of the working class as a class. It is possible, using data from a social survey conducted in 1969 to get a rough idea of the size of the working class in the United States using each of the definitions. ${ }^{49}$ Since this is one of the most basic consequences of alternative definitions of class structure, it is worthwhile going through the exercise of making the calculations.

It is easy enough to estimate the size of the working class within the simple polarization views of the class structure, since for all prac-

49. The data we will use comes from the 1969 Survey of Working Conditions conducted by the Institute of Social Research at the University of Michigan. A deatailed discusssion of this data source can be found in Wright, Class Structure and Income Determination. 
tical purposes the working class is equivalent to the wage-earning population (the few salaried top executives would hardly affect the estimates). It is much more difficult to operationalize the definitions emphasizing the distinction between productive and unproductive labor. It is often difficult from occupational title alone to tell whether a particular activity is productive or unproductive. Furthermore, many concrete positions involve both productive and unproductive labor. Nevertheless, as a very crude approximation, we will estimate the proportions of the population that are productive and unproductive by dividing industrial sectors into productive and unproductive spheres and by dividing occupations into mental- and manual-labor categories. The following definitions will be used:

Mental labor: professionals, technicians, managers (by occupational title), clerks, and salespeople.

Manual labor: craftsmen, operatives, laborers, transportation and services (janitors, barbers, cooks, and so forth).

Unproductive sectors: wholesale and retail trade, finance, insurance, real estate, services, and government.

Productive sectors: agriculture, fishing, mining, construction, manufacturing, transportation, and communications.

We will use the industrial division alone to give an approximate minimum estimate of the number of unproductive wage earners, and the industrial and occupational division combined to give a maximum estimate. In spite of the obvious limitations of these operationalizations, this should give us a rough idea of the size of the unproductive portion of the labor force. ${ }^{50}$

One final distinction is necessary in order to estimate the size of the proletariat according to the definitions we have discussed. In the analysis of both Poulantzas and Carchedi, as well as in my analysis of contradictory class positions, the distinction between supervisory and nonsupervisory labor is quite important. This is the core of Carchedi's "global function of capital," Poulantzas's political criterion for class position, and my analysis of the control of labor power as a dimension of class relations. The data we will use to estimate the size of the working class contain a rather simple division between supervisors and nonsupervisors: each respondent in the survey was asked "Do you supervise anyone on your job?" While this is clearly a rather broad criterion for supervision, nevertheless it should give us

50. By most definitions of productive labor, at least some mental laborers are productive. Such would be the case for engineers and technicians in commodity production. Our estimate based on the unproductive sector and mental labor is thus clearly too large, but it will still give us a sense of the order of magnitude of unproductive labor. 
a general idea of the proportion of the population occupying supervisory positions.

There is, unfortunately, no basis in the present data for properly distinguishing, on an objective basis, between semiautonomous employees (wage earners with control over their immediate labor process) and fully proletarianized workers. The survey did contain, however, a number of subjective questions concerning working conditions. In particular, each respondent was asked to indicate whether the following two statements described their job "a lot," "somewhat," "a little" or "not at all": (1) a job that allows a lot of freedom as to how you do your work; (2) a job that allows you to make a lot of decisions on your own. While these are clearly inadequate questions for operationalizing objective control within work, in order to get an approximate estimate of the size of the working class when autonomy is taken into account we will assume that all nonsupervisory wage earners who answer "a lot" to both of these questions are "semiautonomous employees."

Table 7 presents estimates of the size of the working class for the entire economically active population, and for men and women separately. ${ }^{51}$ It is clear from these estimates that the different definitions of class provide radically differing images of the structural basis for the formation of the working class into an organized class. The simple polarization perspectives see the structural basis of workingclass formation as a large majority of the population, approaching 90 percent. $^{52}$ Those who argue for the existence of a new petty bourgeoisie, however, see the working class in advanced capitalist societies as a relatively small minority. In the United States, depending upon exactly how the new petty bourgeoisie is defined, the working class is somewhere between 20 percent and 40 percent of the population. New-class perspectives that exclude from the working class those wage earners engaged primarily in activities of reproduction rather than production would estimate the size of the U.S. working class at around 60 percent of the population. Finally, when the class structure is conceptualized in terms of contradictory locations within class relations, the working class would be somewhere between 40 and 50 percent of the American population. ${ }^{53}$

51. A more detailed account of the calculation of these estimates can be found in Wright, Class, Crisis and the State.

52. It should be noted that in Cutler et al.'s particular version of the polarization view of class structure, the working class would be somewhat smaller than this, since the authors exclude all people in the state and other noneconomic institutions from the class structure altogether. This would probably reduce the working class in their analysis to something around $60-65$ percent of the population.

53. The estimate of 41.6 percent is undoubtedly too low, even as a lower bound. The 
The Size of the Working Class,

by Diverse Criteria

\begin{tabular}{|c|c|c|c|}
\hline \multirow[b]{2}{*}{ Criteria } & \multicolumn{3}{|c|}{$\begin{array}{c}\text { Percentage of } \\
\text { Economically Active Population } \\
\text { in Working Class } \\
\end{array}$} \\
\hline & Tota1 & Men & Women \\
\hline \multicolumn{4}{|l|}{ Simple polarization view: } \\
\hline All wage earners & $88.0 \%$ & $83.6 \%$ & $95.1 \%$ \\
\hline Productive wage earners & $20-39$ & $23-47$ & $15-26$ \\
\hline Productive sphere & 39.3 & 46.7 & 25.9 \\
\hline $\begin{array}{l}\text { Manual labor in the } \\
\text { productive sphere }\end{array}$ & 30.4 & 38.1 & 16.4 \\
\hline $\begin{array}{l}\text { Nonsupervisory manual } \\
\text { labor in productive } \\
\text { sphere (Poulantzas) }\end{array}$ & 19.7 & 22.7 & 14.6 \\
\hline $\begin{array}{l}\text { Wage earners excluding the } \\
\text { professional-managerial class }\end{array}$ & 63.1 & 56.6 & 82.5 \\
\hline Contradictory class positions & $42-52$ & $32-43$ & $57-68$ \\
\hline $\begin{array}{l}\text { All nonsupervisory wage } \\
\text { earners (Carchedi) }\end{array}$ & 51.9 & 43.4 & 67.7 \\
\hline $\begin{array}{l}\text { Nonsupervisory wage } \\
\text { earners excluding } \\
\text { semiautonomous employees }\end{array}$ & 41.6 & 32.8 & 57.6 \\
\hline
\end{tabular}

SOURCE: Data from 1969 Survey of Working Conditions.

a Defined by professional, technical, and managerial occupations.

Knowing the distribution of the population into classes merely establishes the broadest constraints on class formation. Within those constraints, a wide variety of different forms of class organization and

operationalization of supervision is so vague as to include a fairly large number of nominal supervisors who properly belong in the working class, and the subjective criterion for autonomy undoubtedly inflates that category as well. If we include in the working class those people presently classified as supervisors and semiautonomous employees whose occupations are described in the Dictionary of Occupational Titles as noncomplex (scores of 3 or more on the DOT dimensions of occupations), then the working class increases to 55 percent of the population. Much more refined data on class relations are necessary before adequate estimates can be obtained. 
class struggle are possible. It is impossible, therefore, simply on the basis of the structural analysis to make any strong predictions about the forms and direction of class formation. In order to make such predictions the structural analysis must be combined with an historical analysis of the actual practices of classes organized within such a structure.

Adam Przeworski is very insistent upon the necessity of analyzing the dialectical relationship between the structural characteristics of positions within production relations and the organization of those positions into actual class formations. In discussing the structural positions themselves, Przeworski writes:

These, are, however, only categories of places in the economic relations characterizing a particular formation. The occupants of these places become organized, disorganized and reorganized as classes as the results of class struggles, which are themselves structured by the totality of economic, ideological and political relations characterizing the particular conjuncture. What then are the classes of advanced capitalism? Is the "middle class" indeed a concept that has a place within the Marxist perspective? Are these reproductive and service categories "Ia nouvelle petite bourgeoisie," a fraction of the petite bourgeoisie? Or are the occupants of the reproductive category members of the bourgeoisie while those of the service category, members of the working class? Is the lumpenproletariat a divison of the working class or the petite bourgeoisie?

I have argued that these are incorrectly posed questions; that answers to such questions can be given only in terms immanent to the practice of various movements engaged in the process of class formation. This is not a matter of an "objective" classification, but of understanding the ideological, political and economic constraints upon the practice of various movements which continually form the occupants of the places into classes. . . While solutions of these problems are not arbitrary, they are multiple precisely because more than one solution lies within the limits of determination by relations under which class struggles take place in contemporary capitalism. ${ }^{54}$

While it is important to decipher the structure of those empty places within the social relations of production, there is no simple one-to-one correspondence between those places and organized classes. How those places get translated into actual classes is itself an object of class struggle, or as Przeworski puts it, "The ideological class struggle is a struggle about class before it is a struggle among classes." 55

In terms of Przeworski's analysis, alternative theoretical strategies of defining class structure should be evaluated for their ability to facilitate understanding of the historical process of class formation.

54. Adam Przeworski, "The Process of Class Formation: From Karl Kautsky's The Class Struggle to Recent Controversies" (mimeo, 1976), pp. 51-52. In the version of this essay eventually published (Politics \& Society, vol. 7, no. 4 [1977]) this specific passage was eliminated, although the same general position was expressed.

55. Ibid., p. 28. 
The analysis of contradictory locations within class relations is particularly suited to this task. Contradictory "empty places" within the social relations of production can be viewed as those positions that have the least determinate relationship to potential class formations, and that are, therefore, most potentially open to influence by class struggle. The polar positions within class relations, however, have the most direct link to potential class organization. While class struggles will still shape the ways in which proletarian "empty places" are actually organized as a class, there is no ambiguity about the class into which they are being organized. A structural class map involving contradictory locations within class relations thus makes possible the differential analysis of ways in which class struggle affects how the positions within that structure become formed into organized classes.

Once we distinguish class structure from class formation it becomes possible to ask questions about social and historical conditions that determine different forms of class formation for a given form of the class structure. But to answer such questions sensibly it is important to have a map of the class structure itself that adequately captures the multiple possible outcomes of the process of class formation. This is what the schema of contradictory locations within class relations attempts to accomplish.

The reconstruction of the Marxist theory of class structure reflected in the various debates outlined in this essay is still in its relatively early stages. There is a broad agreement that in order to understand the specificity of the social contradictions and the possibilities of class struggle in late capitalism it is necessary to develop the Marxist conception of classes beyond a simple polarization map of the class structure. However, there is not yet anything approaching consensus among Marxists about how to conceive the complexities of that class structure. In the end, the debate among these contending conceptualizations will be resolved on the basis of their capacity to generate systematic explanations of social conflict and social change, and thus their capacity to aid in the formation of political strategies for social transformation. 